\title{
Correction to: The maxima in northerly wind speeds and wave heights over the Arabian Sea, the Arabian/Persian Gulf and the Red Sea derived from 40 years of ERA5 data
}

\author{
V. M. Aboobacker ${ }^{1}$ (D) P. R. Shanas ${ }^{2} \cdot$ Ebrahim M. A. S. Al-Ansari $^{1} \cdot$ V. Sanil Kumar ${ }^{2} \cdot$ P. Vethamony $^{1}$
}

Published online: 5 January 2021

๑) Springer-Verlag GmbH Germany, part of Springer Nature 2021

Correction to: Climate Dynamics

https://doi.org/10.1007/s00382-020-05518-6

In the original version of the article, in both the Figs. 3 and 4 the plots (a) and (b) were repeated twice.

The original article has been corrected.

Publisher's Note Springer Nature remains neutral with regard to jurisdictional claims in published maps and institutional affiliations.

The original article can be found online at https://doi.org/10.1007/ s00382-020-05518-6.

V. M. Aboobacker

vmaboobacker@qu.edu.qa

1 Environmental Science Center, Qatar University, P.O.

Box 2713, Doha, Qatar

2 CSIR-National Institute of Oceanography, Dona Paula,

Goa 403 004, India 